\title{
Market-Orientation and Its Impact on the Performance of Asia Insurance Company in Kerman Province
}

\author{
${ }^{1}$ Gholamreza Jandaghi, ${ }^{2}$ Mahdi Nik Seresht, ${ }^{2}$ Ali Mokhles, ${ }^{3}$ Hassan Kharazi \\ 1 University of Tehran, Iran, ${ }^{2}$ Qom College, Iran, \\ 3Imam Hossein University, Tehran, Iran \\ *jandaghi@ut.ac.ir
}

\begin{abstract}
The key of successes by service providers can be found in their market-orientation. These are organizations which pay more attention to customers and rivals and attempt to provide services with the highest quality. Present paper has studied experimentally the relationship between market-orientation and performance of agencies and brokers of Asia Insurance Company in Kerman province. Here, the scale of market-orientation in service sector is applied. The methodology is field study and the tool to gather information is questionnaire. Factors analysis shows that there are four hidden aspects in the title of market-orientation: customer-orientation, rival-orientation, organizational responsiveness, propensity to customer satisfaction. Findings suggest that customer-orientation and propensity to customer satisfaction have remarkable impacts on performance relative to other aspects. Rival-orientation has lower impact on performance and organizational responsive has an inconsistency relationship with performance.
\end{abstract}

Keywords: market-orientation, customer-orientation, rival-orientation, responsiveness, customer satisfaction.

\section{Introduction}

Most today trading environments are emerged due to increasingly environmental chaos and competition. Most companies have to find the ways to treat such reality. In this line, managers have seriously attempted to develop a degree of competition in their own trading sector (Sing \& Ranchhod, 2004). Successful managers are those who adapt their organization to current conditions. Such adoption is possible when managers and staff accept tendency to market as a culture and vision (Harries \& Ogbonna, 2001). A key of success in competitive markets is to use creative marketing plans to understand customers' needs and market propensities in any time (Jaworski \& Kohli, 1993). In order to achieve a sustainable growth, companies should use creative marketing plans including advertisements, promotion, packaging, pricing strategy and distribution and to provide their customers with new and significant incentives (motivations). Service organizations should also pay attention to their customers in order to profit and acquire a proper market share. Service organizations such as insurance companies should enhance their services quality and meet their consumers' expectations of requested services in order to achieve their desired performance. What provided by insurance companies are, in fact, intangible services roots in the relationship between customers and employees. Therefore, gathering and analyzing information on customers and rivals are vital to set creative and innovative marketing plans. As such information helps a company to conceive its customers' needs, competitive strategies also cause that they understand activities and threats (Im \& Hussain \& Sengupta, 2008). In this line, academic and job owners' attentions are toward the relationship between market-orientation and organizational performance. However, a wide range of researches on market-orientation is allotted to manufacturing companies and other trading zones while limited works are done in service sector. The relationship between marketorientation and organizational performance is not studied in today service industry. The aim of present paper is to study the impact of market-orientation on service industry performance (Asia Insurance Company) in Kerman province.

\section{Market-Orientation}

Market-orientation is a capability which allows companies to acquire a proper competitive advantage. In other words, market-orientation is defined as a philosophy and a behavior to perceive and determine target customers' needs and as an answer to sale organizations so that they can met customers; needs better than rivals and, as a result, it would create a competitive advantage (Jimenez et al. 2007). Saxe and 
Weitz (1982) state that market-orientation concept has marketing bases which point out mental contribution or business management philosophy and on the basis of integration and coordination to meet customers' needs (Kirca et al. 2009). Market-orientation is central base of marketing. In marketing theory, market-orientation means to make operational the marketing concept. Market-orientation concept can be studied in two directions: trading and behavioral philosophy. As a trading philosophy, market-orientation is shared as a paradigm of values and beliefs in organization which help people to understand organizational tasks and provide them with normal behaviors. The emphasis of behavioral attitudes is on organizational characteristics such as strategy, structure, process and activities (Panigyrakis \& Theodoridis, 2007). Such conceptions are integrating. Therefore, market-orientation is a culture in its highest priority to generate profit and to keep customers' high value so that it respects the interests of other investors and provides norms for organizational development and responsiveness to market information (Jimenez et al. 2007).

Narver \& Slater (1990) state that this culture consists of three behavioral elements: customer-orientation, rival-orientation and inter-functional coordination. Market-orientation shapes organizational culture locus which attempts to create higher organizational performance by emphasis on added-value for customers (LedWith \& Odwyer, 2009). Deng \& Dart (1994) define market-orientation by combining four elements which is too similar to defined structure by Narver \& Slater. These elements include customerorientation, rival-orientation, inter-functional coordination and profit organizing. Although these structures of market-orientation differs each other in some items, they are absolutely adapted over a performance concept and have many commonalities. Cadogam \& Diamantopoulos (1995) made a competitive analysis between the elements defined by Jaworski \& Kohli (1993) and Narver \& Slater (1990). They showed conceptual and performance commonalities between both structures. Finally, Sing and Ranchhold defined this concept by four elements: customer-orientation, rival-orientation, responsiveness and propensity to customer satisfaction.

Customer-Orientation: A seller generates value for buyer only through two methods: by increasing buyers' interests with regard to costs and by decreasing buyers' costs with regard to interests (Narver \& Slater, 1990). In this case, Narver \& Slater (1990) define customer-orientation as follow: an organizational culture which creates certain behaviors effectively and efficiently to generate more value for buyers (Gotteland \& Boule, 2006). Most researchers accept that satisfaction occurs when buyers' expectations are met, that is, product's traits are the same customers wish. It clarifies that companies should meet buyers' expectations. Dissatisfaction is the result of not meeting the expectations. What happens in current buying (e.g. customers' satisfaction/dissatisfaction of buying merchandise) will impact in next purchase decisions (Sing \& Ranchhod, 2004). All managers believe that focus on customer is the core element of market-orientation. They believe that focus on customer includes acquiring information from customers on their needs and preferences (Jaworski \& Kohli, 1993).

Rival-Orientation: Rival-orientation means that a seller knows short term strengths and weaknesses as well as long term strategies and capabilities of its major and potential rivals (Narver \& Slater, 1990). Rival-oriented companies look for determining their weaknesses and strengths. They revise regularly their capabilities to others in terms of skills and knowledge based on people, technical and physical systems, managerial systems, organizational structures, values and cultural norms (Birchall \& Tovstiga, 2005). Rival-orientation breeds innovation and new products (Augusto \& Coelho, 2009).

Responsiveness: In its basic concept, responsiveness refers to answer for expected performance. Respecting the clients is the main point of responsiveness. Employees especially those who involve in delivering services are now without mediator respondents to people in order to respond clients' defined needs (Mir Shahi \& Peidaei, 2007). Jaworski \& Kohli (1993) consider the capability of understanding and responding to markets as key market-orientation key. Market-oriented organizations are able to respond environmental changes better and experience better financial performance. According to what mentioned, market-oriented organizations are able to coordinate environmental changes better and quicker (Alimirzaei, 2009).

Propensity to Customer Satisfaction: The concept of propensity to customer satisfaction is a concept considered by today manufacturing or service organizations as a criterion to measure their work quality. Propensity to customer satisfaction is a key factor for market-orientation in this research. Therefore, organizations need to attract customers' trust and satisfaction in order to achieve this aims by utilizing 
propensity to customer strategy. So, they should pay attention to customers' satisfaction and make continuous efforts to keep current customers and attract new ones by considering economical, social and cultural changes as well as customers' needs (Akbari, 2009).

\section{Organizational Performance}

Organizational performance is in fact financial and nonfinancial performance. To achieve organizational performance, employees' performance expectations are considered. Performance expectation is a kind of expectation by which employees expose what they observe and touch in their organizational performance. In fact, each practice by an organization to improve or to destroy organization affects individuals' attitudes. It is also true in market-orientation issues. If employees or customers feel that the extent of market-orientation and respecting the customer of rival and organizational responsiveness is added, then they expect company's performance improvement in all financial and nonfinancial areas.

Customer satisfaction shapes the core of company's operations and all operations should be in line with meeting customers' needs. Recognizing customers' needs and expectations and responding to posed changes in the market play a key role in company's success. Attempts for more market-orientation is practical through better responds to market needs and attempts to satisfying various groups of customers (Noory Nia, 2007). According to this viewpoint, key indicators of market-orientation include organization's access to widespread information disseminated and processed between organization's internal departments. Finally, organization can respond its strategic customers, rivals and partners by using such information and to adopt market changes (Jimenez et al. 2007). Market-orientation studies address to market-orientation related prerequisites (e.g. climate, contradictory coordination, and structural variables), results (i.e. organizational performance, employees' attitudes, and product innovation) and mediators (competition, environment) (Jimenez et al. 2007).

A wide range of studies on market-orientation are performed in USA (i.e. Jaworski \& Kohli, 1993; Narver \& Slater, 1990). In South East Asia and Japan, market-orientation refers to the efforts by individuals and organizational units to generate high value for customers which lead into high performance. Jaworski and Kohli (1993) found that market-orientation is effective in selecting a set of attractive products. Also, it increases market intelligence which relates to the performance of small companies positively (Led with \& Odwyer, 2009). Jaworksi \& Kohli (1993) and Narver \& Slater (1990) clarify that market-orientation provides a cultural context for organizational learning which helps knowledge development by which the ground is paved for product's competitive advantage (Hsieh et al. 2008). Pelham suggests that a proper market-orientation culture can create appropriate competitive advantages for small enterprises (LedWith \& Odwyer, 2009). Narver \& Slater (1990) state that understanding the relationship between marketorientation and strategies for our cohesive understanding of the share of market-orientation in organizational effectiveness are important (Morgan \& Strong, 1997). Effective decision making in organizations is rooted in understanding rivals and customers which leads into organizational high performance (Panigyrakis \& Theodoridis, 2007). Hunt \& Morgan (1995) confirm that market-orientation mutual respect to customers and rivals is necessary for organizational strategy. Researches show that positive relationship between market-orientation and performance in manufacturing firms is stronger that service firms and such relationship depend on company size and business culture context. Based on researches on the relationship between market-orientation and performance, current study plans to investigate the impact of market-orientation factors on performance.

Therefore, research hypotheses are as follow:

H1: customer-orientation in Asia Insurance Company has a positive impact on organizational performance.

H2: Rival-orientation in Asia Insurance Company has a positive impact on organizational performance.

H3: Responsiveness in Asia Insurance Company has a positive impact on organizational performance.

H4: Propensity to customer satisfaction in Asia Insurance Company has a positive impact on organizational performance. 
Below, research model, methodology and data gathering method are explicated.

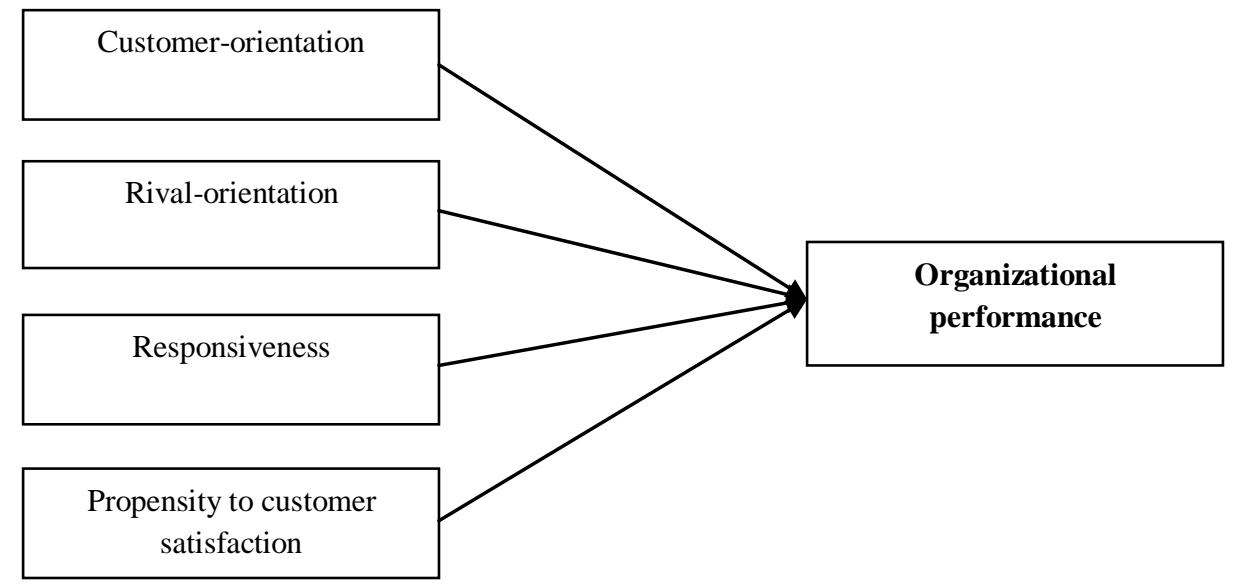

\section{Methodology}

Research population includes the employees of agencies and brokers of Asia Insurance Company in Kerman province. Research type was a field study and the tool to gather information was a 30-item questionnaire. It was the questionnaire provided by Sing \& Ranchhod (2004) that is mixture of items devised by Jaworsky \& Kohli (1993). With a few changes, this questionnaire is used for service enterprises like Asia Insurance Company. 12 items are allotted to customer-orientation, 5 items to rivalorientation, 3 items to responsiveness, 5 items to customer satisfaction and 5 items to measure organizational performance. In present research, performance was assessed by taking employees' opinions. 5-item Likert's range was used which involve form completely opponent to completely proponent. The population included 114 individuals throughout the province. Therefore, questionnaires were sent to all individuals. Alpha Chronbach is used to measure questionnaire reliability. For a 25subject sample, its ratio was 0.84 . Thus, questionnaire reliability was confirmed. Totally, 102 questionnaires were returned.

\section{Results and Discussion}

In this section, T-test is used to analyze data for each variable to determine which factors are important and remarkable for bank customers and should be considered. The results are as follow:

Table 1: t-test for research variables

\begin{tabular}{|c|c|c|c|c|c|c|}
\hline \multirow[b]{2}{*}{ Variable } & \multirow[b]{2}{*}{$\mathbf{T}$} & \multicolumn{5}{|c|}{ Test value $($ mean level) $=3$} \\
\hline & & $\begin{array}{c}\text { Freedom } \\
\text { degree }\end{array}$ & Significance & $\begin{array}{l}\text { Standard } \\
\text { deviation }\end{array}$ & $\begin{array}{l}\text { Confidenc } \\
\text { Low level }\end{array}$ & $\begin{array}{l}\text { level } 95 \% \\
\text { High level }\end{array}$ \\
\hline Customer-orientation & 8.34 & 101 & 0.000 & 0.59 & 0.45 & 0.74 \\
\hline Rival-orientation & 5.92 & 101 & 0.000 & 0.54 & 0.46 & 0.73 \\
\hline Responsiveness & 1.99 & 100 & 0.52 & 0.23 & -0.002 & 0.45 \\
\hline Customer satisfaction & 5.96 & 101 & 0.000 & 0.41 & 0.27 & 0.54 \\
\hline $\begin{array}{l}\text { Organizational } \\
\text { performance }\end{array}$ & 6.11 & 101 & 0.000 & 0.49 & 0.33 & 0.66 \\
\hline
\end{tabular}

As seen in table 1, 4 factors namely customer-orientation, rival-orientation, responsiveness and performance have low level and high positive levels. It shows that responses are higher than average level (3) and are tended toward agree and completely agree. Here, only rival-orientation variable has no difference on average level. Therefore, all above variables excluding rival-orientation have remarkable importance in present paper. Before hypothesis tests, correlation is calculated among variables to determine their extents and relationship types. The results of correlation test are indicated in table 2 . As seen, there is positive and high relationship between customer-orientation and rival-orientation as well propensity to customer satisfaction and performance. There is also a positive and significant relationship between responsiveness and customer-orientation and performance. Below, research hypotheses are tested. 
Table 2: Pearson's correlation test

\begin{tabular}{lcc}
\hline Variable & Correlation & Significance \\
\hline Customer-orientation and rival-orientation & 0.50 & 0.01 \\
Customer-orientation and responsiveness & 0.23 & 0.12 \\
Customer-orientation and propensity to customer satisfaction & 0.52 & 0.000 \\
Rival-orientation and responsiveness & 0.46 & 0.02 \\
Rival-orientation and propensity to customer satisfaction & 0.50 & 0.000 \\
Responsiveness and propensity to customer satisfaction & 0.40 & 0.005 \\
Customer-orientation and performance & 0.71 & 0.000 \\
Rival-orientation and performance & 0.35 & 0.019 \\
Responsiveness and performance & 0.32 & 0.158 \\
Propensity to customer satisfaction and performance & 0.41 & 0.005 \\
\hline
\end{tabular}

H1: In Asia Insurance Company, customer-orientation has a positive impact on organizational performance

H2: In Asia Insurance Company, rival-orientation has a positive impact on organizational performance.

H3: In Asia Insurance Company, responsiveness has a positive impact on organizational performance.

H4: In Asia Insurance Company, propensity to customer satisfaction has a positive impact on organizational performance.

Table 3: the results of linear regression

\begin{tabular}{lllll}
\hline Independent variable & $\begin{array}{c}\text { Dependant } \\
\text { variable }\end{array}$ & $\begin{array}{c}\boldsymbol{\beta} \text { standard } \\
\text { ratio }\end{array}$ & $\begin{array}{c}\boldsymbol{\beta} \text { substandard } \\
\text { ratio }\end{array}$ & $\begin{array}{c}\boldsymbol{\beta} \\
\text { significance }\end{array}$ \\
\hline Customer-orientation & $\begin{array}{l}\text { Organizational } \\
\text { performance }\end{array}$ & 0.69 & 0.69 & 0.000 \\
Rival-orientation & $\begin{array}{l}\text { Organizational } \\
\text { performance }\end{array}$ & 0.34 & 0.34 & 0.019 \\
Responsiveness & $\begin{array}{l}\text { Organizational } \\
\text { performance }\end{array}$ & 0.40 & 0.20 & 0.158 \\
$\begin{array}{l}\text { Propensity to customer } \\
\text { satisfaction }\end{array}$ & $\begin{array}{l}\text { Organizational } \\
\text { performance }\end{array}$ & 0.40 & 0.40 & 0.005 \\
\hline
\end{tabular}

The results in table 3 show that there is a linear relationship between customer-orientation and organizational performance and 1 unit change in customer-orientation leads into 0.69 change in performance. In the meantime, 1 unit change in rival-orientation leads into 0.34 changes in performance and 1 unit change in propensity to customer-satisfaction leads into 0.40 change in performance. However, responsiveness has no significant impact on performance. Therefore, in present study, H1, H3 and H4 are supported and $\mathrm{H} 2$ is rejected. Below, using multivariable regression and inserting variables simultaneously show that there is a correlation (0.71) between market-orientation variables and performance. $51 \%$ of changes (R2) are related to customer-orientation, rival-orientation, responsiveness and propensity to customer satisfaction while $7 \%$ of changes are related to errors in sampling and model. Therefore, after conducting the tests, research model is as follows:

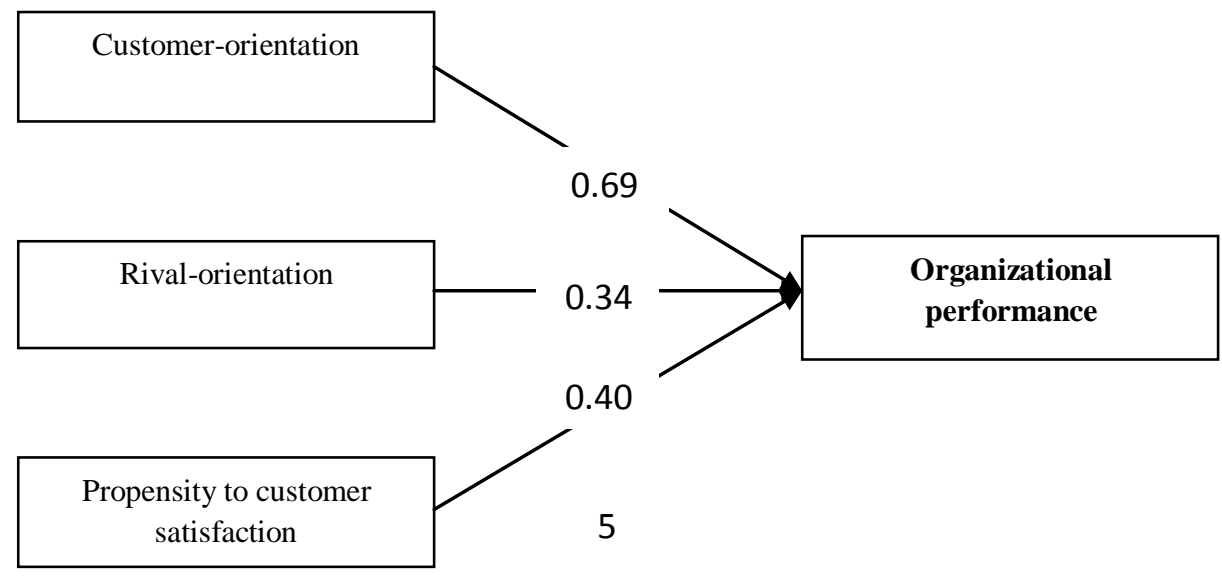


Research by Zheng-zhou et al. (2009) indicates that if a company perceives what its customers should achieve (e.g. emphasizing on service), then it would be adopted to rival-orientation and customerorientation simultaneously. In contrast, if a company thinks that what customers should represent (e.g. emphasizing on price), then it tends to develop rival-orientation. Studying the relationship between market-orientation and competitive advantage clarifies that such event may be happened. Cadogam and Diamantopoulos (1995) show that market-orientation has four separated aspects: customer-orientation, rival-orientation, responsiveness and propensity to customer-orientation and there is high correlation among them. The results of the research indicate that there is a high and significant relationship between customer-orientation and rival-orientation as well as propensity to customer satisfaction and performance. Also, there is a positive and significant relationship between rival-orientation and propensity to customer satisfaction. However, there is no significant relationship between responsiveness and customer-orientation and performance. Although market-orientation is a remarkable concept in developing marketing theory, previous experimental findings show that using this concept does not lead into profit in business necessarily (Chen \& Quester, 2009).

Paramount studies show that increase in market-orientation level leads to high organizational performance (Narver \& Slater, 1990). However, it is generally accepted that there is a significant relationship between market-orientation and performance (Jimenez et al. 2007). The results of a study by Santos-Vijande et al. (2005) show that learning is related to market-orientation and market-orientation has a positive impact on long-term relations with customers which has led into high organizational performance. In another study which investigated the impacts of market-orientation on UK Machinery Industry, the results showed that customer-orientation and propensity to customer satisfaction are effective factors on performance and rival-orientation has a U-shaped relationship with performance. However, a certain and clear relations between organizational responsiveness and performance was not observed. As the findings show, the agents of Asia Insurance Company in Kerman province make high priority for customers and customer-orientation and propensity to customer satisfaction have high impacts on their performance. However, the results for other items are weak so that the correlation between performance and rival-orientation is low and rival-orientation has lower impacts on performance. There is no significant relationship between responsiveness and performance and responsiveness has no significant impact on performance. Although a few aspects of market-orientation such as customer-orientation have high impacts on performance and others have weaker impacts, present study shows like previous results that market-orientation in service companies such as insurance companies have a significant relationship to their performance.

\section{Conclusion}

According to the findings, one can say that customer-orientation in Asia Insurance Company is a remarkable factor for authorities which play a vital role in market-orientation like previous studies. The reason is that the number of its agents and brokers is increasing day-by-day and each one attempts to attract customers. Often, such agents attend in considered locations to save customers' time. There are also 24-hour services through Internet and most agents and brokers provide customers with facilities to pay premium and give a grace period to customers to attract them. It has a positive impact on their performance. However, the results show that these agents do not pay attention to their rivals and rivalorientation in such companies is in low level. Conducted interviews show that Asia Insurance Company should meet adopted insurance laws since it is a public company. Also, the existence of small workshops and paramount discounts on premium granted to customers for their advertisement as well as the lack of laws or sufficient monitoring to prevent offending persons which destroys completion by other agents. This is a main reason of not responding to people and their claims. It means that increase in the number of insurance companies and the participation of private sector with distinguished and qualitative services and the lack of cooperation by brokers to provide unified service and violating the laws has led into the decrease in considered profit. As a result, most agents only attempt to sell insurance services and do not undertake the costs of responding to customers and their claims. So, they do not consider responsiveness as an effective factor on organizational performance and profit. 


\section{References}

Akbari, R. (2009). Survey the effective variables on satisfying customers of MELLAT bank. M.S. Thesis. Imam Sadiq University, Faculty of Management.

Alimirzaei, G. (2009). Survey relationship between market orientation, network learning and entrepreneur ship orientation with organizational innovation. M.S. Thesis. Bahonar university of Kerman, faculty of management.

Augusto, M. \& Coelho, F. (2009). Market orientation and new-to-the- world products: Exploring the moderating effects of innovativeness, competitive strength, and environmental forces. Industrial Marketing Management, 38(1), 94-108.

Birchall, D. \& Tovstiga, G. (2005). Capabilities for strategic advantage, Palgrave Macmillan

Cadogan, J. W. \& Diamantopoulos, A. (1995). Narver and Slater, Kohli \& Jaworski and the Market Orientation Construct: Integration and Internationalization, Journal of Strategic Marketing, 3(1), 41-60.

Chen, C. \& Quester, G. P. (2009). A value-based perspective of market orientation and customer service. Journal of Retailing and Consumer Services, 16(3), 197-206

Deng, S. \& Dart, J. (1994) Measuring market orientation: A multifactor, multi-item approach. Journal of Marketing Management, 10(8), 725-742.

Gotteland, D. \& Boule, J-M. (2006). The Market orientation- new product performance relationship: Redefining the moderating role of environmental conditions. International Journal of Research in Marketing, 23(2), 171-185.

Harries, L. \& Ogbonna, E. (2001). Leadership style and market orientation: An empirical study. European Journal of Marketing, 35(5/6), 744-764.

Hsieh, M., Tsai, K. \& Wang, J. (2008). The moderating effects of market orientation and launch proficiency on the product advantage- performance relationship. Industrial Marketing Management, 37(5), 580-592.

Hunt, S. D. \& Morgan, R. M. (1995). The Comparative Advantage Theory of Competition. Journal of Marketing, 59, 1-15.

Im, S., Hussain, M. \& Sengupta, S. (2008). Testing interaction effects of the dimensions of market orientation on marketing program creativity. Journal of Business Research, 61(8), 859-67.

Jaworski, B. J. \& Kohli, A. K. (1993). Market orientation: Antecedents and consequences. Journal of Marketing, 57(3), 53- 70.

Jimenez, D., Cegarra, G. \& Navarro, J. (2007). The performance effect of organizational learning and market orientation. Journal of Industrial Marketing Management, 36(6), 694-708.

Kirca, A. Cavusgil, S. T. \& Hult, G. T. (2009). The effects of national culture on market orientation: conceptual framework and research propositions. International Business Review, 18, 111-118.

LedWith, A. \& Odwyer, M. (2009). Market orientation, NPD Performance, and organizational performance in small firms. J Product development \& management Association; 26, 652-661.

Mir Shahi, S. \& Peidaei, M. (2007). Responsiveness principles 1. Tafahom Magazine.

Morgan, R. \& Strong, C. (1997). Market orientation and dimensions of strategic orientation. European Journal of Marketing; 32(11/12), 1051-1073.

Narver, C. J. \& Slater, F. S. (1990). The Effects of a Market Orientation on Business Profitability, Journal of Marketing, 54, 20-35.

Noory- Nia, R. (2007). Market orientation, the heart of marketing. Tadbir Magazine, 181, 17-25.

Panigyrakis, G. G. \& Theodoridis, K. P. (2007). Market orientation and performance: An empirical investigation in the retail industry in Greece. Journal of Retailing and Consumer Services; 14(2), 137-149.

Santos-Vijande, M., Sanzo-Peres, M. \& Alvarez-Gonzales, L. (2005). Organizational learning and market orientation: interface and effects on performance. Industrial Marketing Management. 34, 187-202

Saxe, R. \& Weitz, B. A. (1982). The SOCO Scale: A Measure of the Customer Orientation of Salespeople, Journal of Marketing Research, 19(3), 343-351.

Sing, S. \& Ranchhod, A. (2004). Market orientation and customer satisfaction: Evidence from British machine tool industry. Industrial Marketing Management, 33(2), 135-144.

Zheng-Zhou, K. R., Brown, J. S. \& Dev, C. (2009). Market orientation, competitive advantage and performance: A demand- based perspective. Journal of Business Research, 62(11), 1063-1070. 